\begin{tabular}{|c|c|c|c|c|c|c|c|}
\hline Experimental groups & $\begin{array}{c}\text { Total } \\
\text { No. of } \\
\text { animals }\end{array}$ & $\begin{array}{c}\text { Animals dying } \\
\text { with marrow } \\
\text { depression }\end{array}$ & $\begin{array}{l}\text { Animals surviving beyond } \\
14 \text { days and those dying } \\
\text { before } 14 \text { days with } \\
\text { microscopie rejection }\end{array}$ & $\begin{array}{l}\text { Animals surviving } \\
\text { beyond } 20 \text { days } \\
\text { with good renal } \\
\text { function }\end{array}$ & $\begin{array}{c}\text { Animals dying after } \\
14 \text { days without } \\
\text { microscopic } \\
\text { rejection }\end{array}$ & $\begin{array}{l}\text { Animals } \\
\text { surviving } \\
\text { beyond } 3 \\
\text { months }\end{array}$ & $\begin{array}{c}\text { Mean } \\
\text { survival } \\
\text { time }\end{array}$ \\
\hline \multirow{2}{*}{$\begin{array}{l}\text { Thymectomy/actinomycin } \\
\text { C/'Imuran' } \\
\text { Actinomycin } C / \text { 'Imuran' } \\
\text { (series II) }\end{array}$} & 8 & 4 & 7 & 4 & 1 & 0 & 17 \\
\hline & 11 & 5 & 8 & 3 & 4 & 0 & 17 \\
\hline
\end{tabular}

The results of the experiments are shown in Table 1, where a comparison is made with similar experiments performed without thymectomy.

The control experiments were performed concurrently in the same laboratory and have been reported elsewhere ${ }^{3}$. It can be seen that thymectomy has not improved the length of survival of functioning renal transplants. Examination of the thymuses of the animals treated with the thiopurine and actinomycin drug combination showed a very marked diminution in size of the organs and a severe depletion of lymphoid follicles.

In the context of these experiments it would appear that if the thymus has an important role in the rejection of canine renal transplants in adult animals, then the drugs used in this study can inhibit this effect so that surgical thymectomy has no additional advantage.

I thank Miss Leigh Brown for assistance, and Dr. G. H. Hitchings and his colleagues of Burroughs Wellcome, Inc., for their co-operation in this work and also for providing the purine analogues. I also thank Dr. D. Whitfield, of F.B.A. Pharmaceuticals, Ltd., for providing the actinomycin $C$. This work was financed by grant $G-62-29$ from the Life Insurance Medical Research Fund.

Westminster Hospital Medical School,

$$
\text { R. Y. CALNE }
$$
London, S.W.1.

${ }^{2}$ Miller, J. F. A. P., Lancet, i, 43 (1963).

${ }^{2}$ Calne, R. Y., Alexandre, G. P. J., and Murray, J. E., Ann. N.Y. Acad. Sci., 99, 743 (1962).

${ }^{3}$ Calne, R. Y., Ann. Roy. Coll. Surgeons, 32, 281 (1963).

\section{Degraded Carrageenan and Experimental Acute Gastric Ulceration in the Guinea Pig}

IT has been shown ${ }^{1}$ that histamine-induced peptic ulceration in the intact unanæsthetized guinea pig can be prevented or diminished by the oral administration of the sulphated polysaccharide, degraded carrageenan; severe duodenal ulceration could be completely prevented by a dose which at the same time approximately halved the severity of gastric ulceration. It was suggested that degraded carrageenan might augment the natural protection afforded by mucin by complexing with it, so providing a more robust mucosal coating. It has since also been found $^{2}$ that in the guinea pig the volume and acidity of histamine gastric secretion is reduced by prior oral administration of degraded carrageenæn.

In the experimental results reported here another factor in the protective action of degraded carrageenan on the stomach is described. Acute gastric ulceration caused by histamine has been decreased by the intraduodenal injection of a solution of degraded carrageenan in random bred, male albino guinea pigs of one strain (weight range 300$500 \mathrm{~g}$ ), where the junction of stomach and duodenum has been sealed by application of a clip or by ligation.

Gastric ulceration was produced in the anæsthetized ('Nembutal' sodium $30 \mathrm{mg} / \mathrm{kg}$ intraperitoneally) guinea pig by the subcutaneous administration of histamine acid phosphate $(5.0 \mathrm{mg} / \mathrm{kg}$ in saline). The peritoneal cavity was opened and an artery clip or ligature placed on the duodenum above the bile duct, to prevent communication between the contents of the duodenum and stomach. $200 \mathrm{mg}$ degraded carrageenan in $1 \mathrm{ml}$. water were injected

into the duodenum in the direction of the pylorus $0.5 \mathrm{~h}$ before administration of histamine, and again immediately after the histamine was given; control animals received $1 \mathrm{ml}$. water instead of degraded carrageenan solution. In a further group of control animals treated similarly but receiving neither histamine nor degraded carrageonan the stomach was apparently healthy at the end of the experiment. The peritoneal cavity was closed by artery forceps and the animal left covered in the supine position on a warm table until $1 \mathrm{~h}$ after the injection of histamine, when it was killed by ether. The stomach was removed with the clip in position and the gastric secretion collected. It was filled with water and examined by transmitted light for ulceration. Only clearly established ulcors were considered and these appeared as clean, virtually trans. parent areas sharply bounded by a whitish opaque margin. This corresponds to the established ulcer carefully described by Watt ${ }^{3}$.
Table 1. Anti-gastric Ulcer Effect of Degraded Carrageenan Treatment No. of animals Average severity of
Control (water)
Degraded carrageenan
14
gastric ulceration

A $4+$ scale was used to grade severity of ulceration: + indicates one or two small areas of ulceration; $2+$, one or two larger areas; $3+$, several areas of marked ulceration; 4+, extensive ulceration with confluence or impending perforation. Results were averaged for each group and are shown in Table 1.

Thus, 50 per cent reduction in gastric ulceration in $1 \mathrm{~h}$ is effected by the sulphated polysaccharide without gaining access to the gastric contents; and this protection compares with that reported ${ }^{\mathrm{l}}$ in a 24 -h experiment where a rather larger (but oily and intramuscular) dose of histamine produced less-severe gastric ulceration, and where a much larger dose of degraded carrageenan was used.

It is suggested that the protection from gastric ulceration given by degraded carrageenan is brought about by events which are initiated in the intestine and probably in the duodenum.

We thank Evans Medical, Ltd., for a gift of degraded carrageenan ('Ebimar').

School of Pharmacy,

W. Anderson

P. D. Soman

The Royal College of Science and Technology, Glasgow, C.1.

I Anderson, W., and Watt, J., J. Physiol., 147, 52 P (1959).

2 Anderson, W., Mareus, R., and Watt, J., J. Pharm. Pharmacol., 14, 119 T (1962).

${ }^{3}$ Watt, J., Gastroenterol., 37, 741 (1959).

\section{HFMATOLOGY}

\section{Evidence that 'Normal Incomplete Cold Antibody' is not a Gamma-globulin}

DACIE $^{1}$ discovered that if normal human red cells were left at $0^{\circ} \mathrm{C}$ with their own fresh serum and afterwards washed in warm saline, they could be agglutinated by anti-human globulin serum, and he postulated that serum normally contained an incomplete antibody reacting at $0^{\circ} \mathrm{C}$ with human red cells. Later, Dacie, Crookston and Christenson ${ }^{2}$ produced evidence that the positive antiglobulin reactions were not due to the direct detection 